\title{
The Value Added Properties Of Local Historical Preservation Districts
}

David Gordon, Ph.D., University of Saint Francis, Illinois, USA

Richard Vaughan, Ph.D., University of Saint Francis, Illinois, USA

\begin{abstract}
This paper explains what is meant by having real property or entire districts designated as historically significant. The economic and social significance of such a designation is explored. The role of a local historic preservation commission is addressed. It is shown that such an organization enhances the benefits of a historical designation by eliminating informational asymmetries. A simple economic model is developed demonstrating the valuation changes arising from the benefits of the historical designation. Difference in difference models along with hedonic regression models are explained. Empirical results from these models are surveyed. The topic of sustainability and how it increases social value is also approached.
\end{abstract}

Keywords: Hedonic Regression; Asymmetric Information; Preservation District

\section{INTRODUCTION}

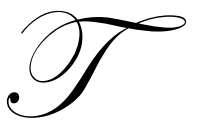

he purpose of this paper is to demonstrate the benefits of having an active and governmentally supported local historical preservation district commission. The role of the commission is of course to ensure the historical preservation of the district in question. This paper will also show the several types of benefits that accrue not only to the historical preservation district itself, but also to the surrounding commercial and residential community. These benefits exist even in preservation districts without any local ordinances regarding land use in place, but are much more pronounced where local ordinances are used. A simple economic model will be utilized to help illustrate some of these direct and indirect benefits. More formal models including hedonic regression models will also be explained. Empirical results utilizing these models will also be reported. The presence of such a district also contributes in a very positive manner to the burgeoning community emphasis on sustainability. The essential role played by the local preservation commission in supplying valuable information to the real estate market will also be explored.

\section{SIGNIFICANCE OF HISTORICAL DESIGNATION}

The main rationale for having an area within a city or town designated as being historically significant is to provide a means of protecting the area from physical deterioration. The National Historic Preservation Act gives the U.S. Secretary of the Interior the authority to designate a building or district as being historically significant. Upon receiving this designation the building or district is given official recognition by being placed on the National Register of Historic Places which is most commonly referred to as the National Register. Although this national honor offers some protection for the sites listed in the register it does not guarantee the maintenance of such sites. Physical deterioration of the buildings in question might still occur. This is where the local preservation commissions play such an important role. They are truly the front line enforcers of maintaining and preserving the substance and value creating nature of the historic sites and neighborhoods. Local preservation districts have the biggest impact when the following two conditions exist: clearly written and publicized guidelines for all affected properties and active educational outreach to the real estate community including brokers, owners, architects and bankers. These two conditions are predicated by the existence of a fully staffed local preservation historical committee which makes consistent and predictable decisions. 


\section{EFFECTS ON DEMAND}

Although the main reason for historical designation relates to preventing the deterioration of buildings and thus maintaining their value a secondary effect also is prevalent. This relates to a positive spillover effect on commercial and especially residential properties within and surrounding the historical district. A simple supply and demand model can be used to demonstrate the increase in property values. We will assume that the demand for properties is a negative function of price and a positive function of both household income and an active local historical preservation district commission. Graphically this means that when the desired quantity demand (horizontal axis) for properties is plotted against the property values (vertical axis) the demand curve will have a downward (negative) slope. Increases in household income would cause the demand curve to increase (shift to the right). In other words we are assuming that properties are a normal good. The Preservation Economic Impact model developed at Rutgers University demonstrates that historical preservation results in more job creation than new construction thus creating higher household income which in turn enhances the demand for properties. The presence of, and higher activity level of, the local preservation commission would also cause an increase in demand. Any increase in demand would cause property values to increase.

There are several reasons why a direct relationship exists between the presence and activities of the commission and the demand for properties. First of all the commission plays an important role in seeing that land use ordinances are abided by. The preservation of such properties encourages potential buyers of property that the neighborhood will not be permitted to decay over time. This would also provide incentives for property owners surrounding the district to revitalize their properties. Secondly, the commission serves to reduce informational asymmetries that might exist in real estate markets. Asymmetric information exists when the buyers and sellers have different information sets. Normally a seller would possess a more vast quantity of information about a property than a potential buyer. Real estate brokers do offer warranties that sellers can attach to their properties which can reduce the information differences, but these add to the cost of the property and thus discourage demand. One important implication of an information asymmetry is that demand is reduced and subsequently real estate values are reduced. Adverse selection might arise where too few of the higher quality properties normally associated within and around a historical district become sold. The historical preservation commission provides additional important information about the nature, significance and quality of structures within the district and thereby reduces or eliminates informational asymmetries. This is turn stimulates demand and prices for the properties within and surrounding the historical district.

\section{EFFECTS ON SUPPLY}

We will assume that the supply of properties for sale are a direct function of real estate prices and an indirect function of tax benefits of property ownership, favorable neighborhood effects, stronger sense of community and land use ordinances. As with demand, real estate values are measured on the vertical axis and quantity of properties for sale on the horizontal axis. Since a positive relationship is assumed to exist between these two variables the supply curve would have a positive slope. Increases in tax benefits, neighborhood effects, sense of community, and land use ordinances would all cause the supply to decrease which would be shown as a leftward shift in the supply curve. Any decrease in supply would cause property values to increase.

The active presence of a local historic preservation committee can lead to a national government designation such as a listing in the National Register of Historic Places. Such a designation comes with substantial tax benefits such as a federal tax credit for the rehabilitation and maintenance of the designated properties. The known presence of these tax benefits would provide an incentive for current property owners to maintain and retain their real estate therefore decreasing the supply of properties for sale on the market. The tax benefits might not be known to the general public. The local commission can once again play a vital role in disseminating this important information. A firmer sense of community or attachment to a community would further serve to reduce the supply of property for sale. If property owners have an emotional attachment to the area they of course will be reluctant to relocate their residence or business operation. Local land ordinances also have the advantageous effect of keeping properties off the market. 


\section{VALUATION DIFFERENCES}

The historical designation along with an active local historic preservation commission leads to the aforementioned changes in supply and demand. These changes in turn lead to an increase in the values of properties within the district. (Appendix \#1 shows how a decrease in supply from S1 to S2 along with an increase in demand from D1 to D2 results in higher property values.) Properties near the historic district also will see similar changes in supply and demand and thus similar changes in property values. Here we can employ what we will call the Disney World Effect. Before Disney World opened in central Florida the area was essentially worthless swamp land. When the theme park opened in 1971 the land that Disney World occupied increased exponentially in value. But as we now know, the value of land surrounding Disney World also increased exponentially in value. This is a type of neighborhood effect. Increases in property values do indeed appear to be contagious.

The academic literature abounds with examples of rigorous studies showing the positive effects that historical preservation districts have on the value of real property within the district and surrounding the district. Most of these types of studies utilize one of two accepted valuation models: difference in difference models or hedonic regression models. The difference in difference models are the easier of the two to utilize. This model involves computing a sample mean for the growth rates in property values within and surrounding an historical district and also a sample mean for the growth rate of property values clearly outside the district. A statistical test is then performed checking to see whether or not there is a significant difference in the growth rates. The major problem with this type of study is that no specific variables are controlled for. The averages mask the probable significance of the variety of differences that exist in the many properties themselves. These would include square footage differences, number of bedroom differences and the condition of the property. The hedonic regression model is thought to be superior to the difference in difference models. This type of model provides a means to estimate the implicit value of various structural characteristics of a property. It allows for an accurate assessment of the extra value given to a property with historic designation while controlling for specific property and neighborhood characteristics. In this type of theoretical model we assume that utility is a function of a vector of attributes of the property and a composite attribute of all other goods. The problem that a household must solve is to maximize this utility subject to a budget constraint involving rental prices for houses and a unit price for the composite good and also subject to a linear transformation technology that relates attributes to the housing stock. Statistical hedonic models typically include the natural $\log$ of the property price as the dependent variable and structural and neighborhood characteristics as well historic preservation district status as the independent variables . (The semi-log form of the model is normally used, because then the coefficients on each explanatory variable can be interpreted as percentage changes in the property price given a one unit change in the independent variable.)

\section{SAMPLING OF EMPIRICAL RESULTS}

Both types of studies confirm statistically significant extra positive values associated with properties within and surrounding a district identified as historically significant. Examples of such studies include Ford (1989), Leichenko, Coulson and Listokin (2001), Clark (1997), Coffin (1989), Linneman (1980), Rypkema (1994, 2002, 2005), and Listokin, Listokin and Lair (1998). Many of these studies see additional benefits to property values when known local land ordinances exist alongside a local preservation district. Market failures, due to informational asymmetries, resulting in lower property values might arise if these benefits are not publicly pronounced. The local historic preservation commission would play this important role.

\section{SUSTAINABILITY AND SOCIAL VALUE}

Historical preservation districts also add social value. Sustainability is currently receiving positive recognition in both private and public markets. Notable economist and historical preservationist Donovan Rypkema equates sustainable development with historic preservation. When given all the embodied energy found in older residential and commercial properties filled with bricks, metals, concrete and other materials, sustainability advocates point out the negative impact of destroying the current resources and creating a new building made of all new material. (Embodied energy is defined as all the resources expended during the construction of a building. These can include raw materials as well as the electric, gas energy and human capital that went into the construction of the components and the building itself.) 
The new phrase emerging from the topic of sustainability states that "the greenest building is the one that is already built." Rehabilitating historic buildings can be a sound sustainable strategy of promoting energy efficiency by preserving the energy already represented in existing buildings (embodied energy), rather than waste additional energy building with a new structure with all new material. It is estimated that a new energy-efficient office building that includes as much as 40 percent recycled materials would take approximately 65 years to recover the energy lost in demolishing a comparable existing building.

The EPA has estimated that building construction debris constitutes around a third of all waste generated in this country, and has projected that over $27 \%$ of existing buildings in the United States will be replaced between 2000 and 2030. Very few historic buildings are structurally unable to be saved; most common issues are nonrepairable structural damage, dangerous materials (asbestos, lead paint) or location issues (earthquake, contaminated soil). Many preservationists point out that the main issue with the new green building movement, which still only accounts for less than one percent of all newly constructed buildings, is that preserving existing buildings may be the greenest approach.

Preserving an older building is often called the ultimate recycling project, yet preservationists commonly fight the perception that historic structures are terribly inefficient and require expensive and drastic corrective measures to retrofit for an energy saving return on investment.

\section{AUTHOR INFORMATION}

David Gordon, DBA is an assistant professor in the College of Business and Health Administration at the University of Saint Francis (USF), Joliet, Illinois. He teaches both graduate and undergraduate classes in finance and economics. Prior to joining USF he held faculty positions at Illinois Valley Community College, the University of Illinois-Chicago and Governors State University. David was awarded numerous teaching awards during his academic career. Prior to earning his Doctorate in Business Administration he received a MA degree in economics and a BA degree in Finance from the University of South Florida in Tampa. He is currently a member of the American Economic Association, the International Financial Management Association, the National Association of Forensic Economics, the History of Economics Society, the Southern Economics Association and the Southern Finance Association. His research interest includes public finance, labor economics and forensic economics. He has published articles in various business and economics journals. E-mail: dgordon@stfrancis.edu. Corresponding author.

Richard Vaughan, DM joined the faculty at the University of St. Francis in 2006 after working 22 years in business and earning numerous awards in marketing and operations for a fortune 100 information company. He has served as Director of Marketing with full P\&L ( $\$ 480 \mathrm{M}$ revenue) portfolio management across the nation. Responsibilities included; providing strategic direction, conducting competitive analysis, and developing best in class strategy, structure and process improvement. He has also held several upper level management positions in operations serving fortune 100 customers. Rich received his Bachelor of Arts from DePaul University, his Masters of Science in Management and Organizational Behavior from Benedictine University and a Doctorate of Management in Organizational Leadership from the University of Phoenix. Rich holds numerous technical and project management certificates and is a Registered Communications Distribution Designer (RCDD). He teaches graduate and undergraduate classes in marketing and management both online and in the classroom. His research interests include marketing technology, sustainable business models and strategy development. E-mail: rvaughan@stfrancis.edu.

\section{REFERENCES}

1. Bender, Bruce and Hae-Shin Hwang, Hedonic Price Indices and Secondary Employment Centers, Journal of Urban Economics, Vol. 17, No. 1, pp. 90-107, 1977.

2. Clark, David, Historical Preservation Districts and Home Sale Prices: Evidence from the Sacramento Housing Market, The Review of Regional Studies, Vol. 27, No. 1, pp. 29-48, 1997.

3. Coffin, Donald, The Impact of Historic Districts on Residential Property Values, Eastern Economic Journal, Vol. 15, No. 3, pp. 221-228, 1989. 
4. Coulson, N. E. and Robin Leichenko, The Internal and External Impact of Historical Designation on Property Values, Journal of Real Estate Finance and Economics, Vol. 23, No. 1, pp. 113-124, 2001.

5. Epple, Dennis, Hedonic Prices and Implicit Markets: Estimating Demand and Supply Functions for Differentiated Products, Journal of Political Economy, Vol. 95, No. 1, pp. 59-80, 1987.

6. Ford, Deborah A., The Effect of Historic District Designation on Single Family Home Prices, American Real Estate and Urban Economics Association Journal, Vol. 17, No. 3, pp. 353-362, 1989.

7. Freeman III, A. Myrick, The Benefits of Environmental Improvement: Theory and Practice, Johns Hopkins University Press, Baltimore, Maryland, 1979.

8. Green, G.P. and A. Fleischmann, Promoting Economic Development: A Comparison of Cities, Suburbs and Non-metropolitan Communities, Urban Affairs Quarterly, Vol. 27, No. 1, pp. 145-153, 1991.

9. Hyman, David N., Public Finance: A Contemporary Application of Theory to Policy, $10^{\text {th }}$ ed., SouthWestern, Mason, Ohio, 2011.

10. Keat, Paul G. and Philip K. Y. Young, Managerial Economics: Economic Tools for Today's Decision Makers, $6^{\text {th }}$. Ed., Prentice Hall, Upper Saddle River, New Jersey, 2009.

11. Lancaster, Kelvin, Consumer Demand: A New Approach, Columbia University Press, New York, New York, 1971.

12. Leichenko, Robin M., N. Edward Coulson and David Listokin, Historic Preservation and Residential Property Values: An Analysis of Texas Cities, Urban Studies, Vol. 38, No. 11, pp. 1973-1987, 2001.

13. Linneman, Peter, Some Empirical Results on the Nature of the Hedonic Price Function for the Urban Housing Market, Journal of Urban Economics, Vol. 8, No. 1, pp. 47-68, 1980.

14. Listokin, D., Barbara Listokin and Michael Lair, The Contributions of Historic Preservation to Housing and Economic Development, Housing Policy Debate, Vol. 9, No. 3, 1998.

15. Palmquist, Raymond, Estimating the Demand for Characteristics of Housing, Review of Economic and Statistics, Vol. 66, No. 3, pp. 394-404, 1983.

16. Pindyck, Robert S. and Daniel L. Rubinfeld, Microeconomics, Pearson Prentice Hall, Upper Saddle River, New Jersey, 2009.

17. Rosen, Sherwin, Hedonic Prices and Implicit Markets: Product Differentiation in Pure Competition, Journal of Political Economy, Vol. 91, No. 1, pp. 34-55, 1973.

18. Rypkema, Donovan D., The Economic Effect of National Register Listing, CRM, Vol. 17, No. 2, 1994.

19. Rypkema, Donovan D., The (Economic) Value of National Register Listing, CRM, Vol. 25, No. 1, 2002.

20. Rypkema, Donovan D., The Economics of Historic Preservation: A Community Leader's Guide, National Trust for Historic Preservation, Washington, D.C., 2005.

21. Varian, Hal R., Intermediate Microeconomics: A Modern Approach, $4^{\text {th }}$ ed., W.W. Norton and Company, New York, New York, 1996. 


\section{APPENDIX \#1}

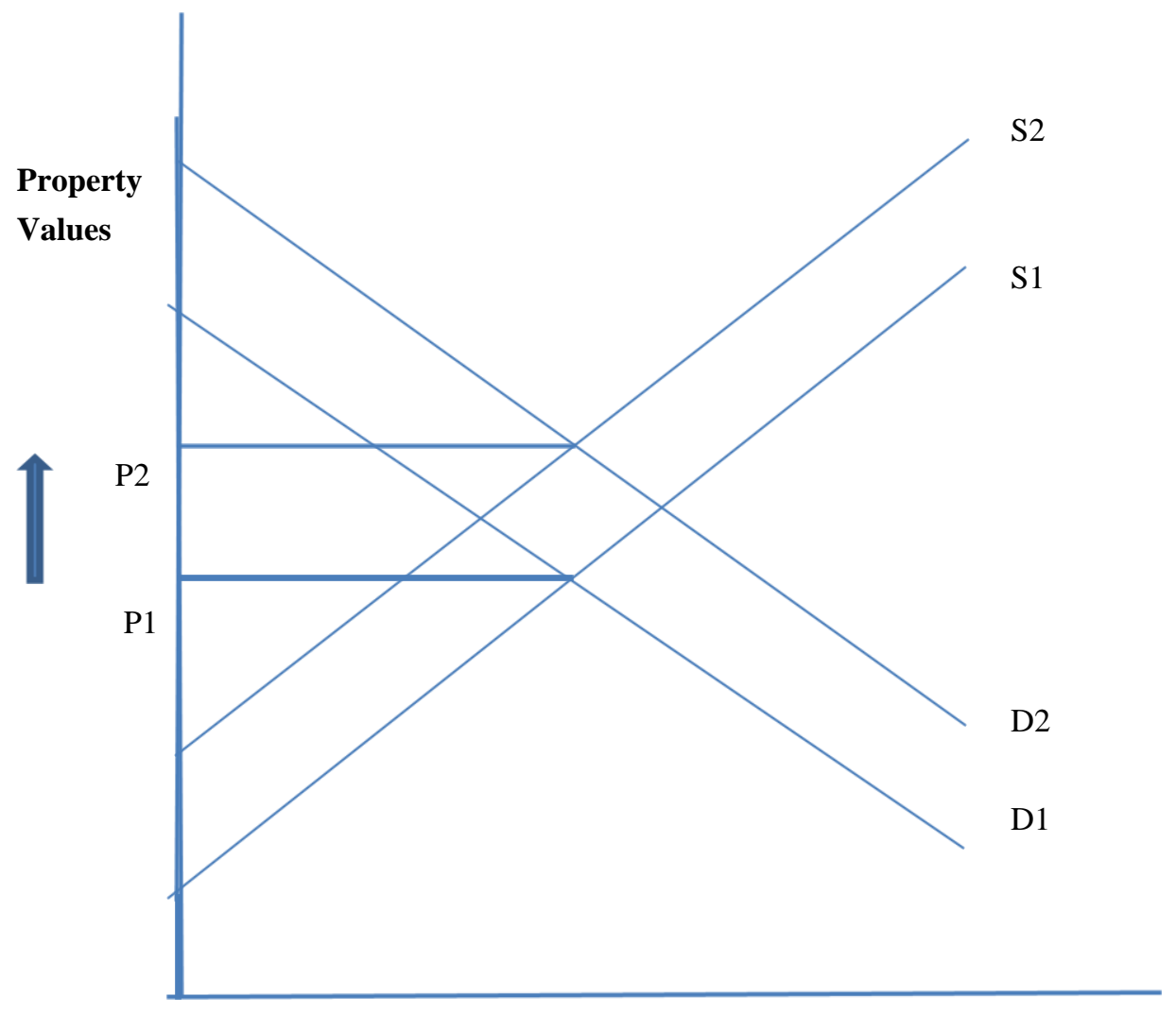

0

Quantity 